\title{
Building Creative and Innovative Learning for Exhibition Through the Concept of Collaborative Knowledge Creation in Polytechnic
}

\author{
Iis Mariam*, Nining Latianingsih, Endah Wartiningsih \\ Business Administration Department \\ State Polytechnic of Jakarta \\ Jakarta, Indonesia \\ *iis.mariam@yahoo.com
}

\begin{abstract}
In the current era of disruption where information technology has a large impact and influence on the development of higher education in Indonesia. The educational pattern at Polytechnic is currently encouraged to be more innovative in an effort to help the government realize the quality of human resources that are reliable and professional in meeting the needs of industry and companies so that they have high organizational competitiveness. One factor that contributes to improving organizational competitiveness is the ability of lecturers to create learning process with creativity and innovative learning situations. Polytechnic learning must be more practical than theory. This research focus in to Diploma 4 MICE study programs (meetings, incentive, conferences, exhibitions) and D3 Business Administration in organizing exhibitions as part of the Exhibition and Sales Administration subject. The role of the lecturer in the learning process becomes a co-learner for students in the implementation of the exhibition. The purpose of this study is to find out: (a) how the concepts used by the lecturers in creating creativity and innovative teaching and learning processes through the concept of collaborative knowledge creation in the exhibition? (b) What learning methods are most suitable to be applied in exhibition subject? and (c) How do the results of creative and innovative learning affect to the students? The study was carried out in two study programs, such as the D4 MICE and D3 AB-PNJ study programs, using qualitative research methods such as soft system thinking (SSM) which compares the existing real conditions with the model that occur to produce a better understanding of objects research. SSM implementation dynamic human activities as a system through the concept of CATWOE (customers, actors, transformation, welstanchaung, owner, environment). Data collection techniques use: interviews, documentation studies and observations. The results of the study show that the role of the lecturer refers to collaborative knowledge creation and problem based learning, problem based education must provide a student learning experience that is applicable, creative, innovative, has a sense of business. The result is students become more confident, creative, innovative, communicative and can create business opportunities. Creative learning focuses on: real phenomena that occur in society, industry, organizations and companies, external campus environmental factors and learning media.
\end{abstract}

Keywords-collaborative knowledge creation, exhibition, creative and innovative learning, soft system methodology

\section{INTRODUCTION}

Education in the current era of disruption must adapt to the changes caused by the speed of access to information technology that has an impact on learning and teaching patterns in universities including at the Polytechnic. One of the factors that contribute to improving organizational competitiveness is the ability of lecturers to create conducive, creative and innovative learning situations through applied science learning strategies. Referring to the new paradigm that in the current era of disruption that requires new skills for new jobs (new skills for new jobs), creative, innovative, problem based learning and problem based education become one of the ways in which the teaching and learning process is given to students to produce student creativity and innovation that not only has hard skills but also soft skills. The purpose of this study is to find out: (a) how is the concept of learning strategies used by lecturers in the Coffee in Town Exhibition and ANEXPO-PNJ if it is related to the concept of collaborative knowledge creation? b) What learning methods are most suitable to be applied in exhibition activities? and (c) How do the results of creative and innovative learning affect students?

The pattern of education in higher education is the existence of creative imagination [1]. Although the logic of inductive and deductive thinking has been able to describe precisely a particular part of the way science works, the description generally leaves the role of the creative imagination of the scientist himself in the work of science. Teachers and lecturers need to think creatively-innovative and have creative imagination, dare to relate, dialogue in a field of religious knowledge in terms of discussion, discussion and encounter with scientific disciplines and other traditions. If this step is not carried out, lectures in higher education will eventually be threatened by the loss of relevance to the problems of surrounding life, the life of the nation, state and as citizens of the world, which of course is increasingly complex [1]. While Forte states that a good education system gives students the freedom to recognize the abilities and potential they have and education should encourage students / students to collaborate in building questions and creativity, high discipline, developing ideas and having a different personality [2]. Forte said that the freedom of students in learning requires collaboration from 
lecturers in teaching and creating a teaching and learning atmosphere that is closer to students, creative teaching makes changes and accepts new things expressed in the teaching process and not afraid to attend fire of change [2]. Creative teaching can be done in two ways, namely: (a) teaching is carried out creatively, and (b) teaching to be creative [3]. The creativity that arises is usually born based on: (1) Knowledge that can encourage someone to understand each other and have an impact on someone creative, (2) the creativity of thinking that is related to one's approach to solving problems and depends on personality and way of thinking or style of work and (3) the emergence of motivation that is generally accepted as one of the creativity produced and the most important is the existence of motivators who have attitudes and interests to be able to work independently. Learning styles is one of the most widely used terms in relation to student learning. In adult learning the characteristics of learning can be seen from how to make learners able to learn by themselves, have rich experiences about learning, are ready to learn when knowledge and experience are needed, more focused and have the motivation to change and learn to solve problems.

Collaborative knowledge creation (CKC) in developing organizational learning processes is an important step that must be done to produce products in the form of knowledge, services and technology that are built through three main models, namely [4,5]: knowledge creation model, expansive learning models, and building knowledge models. There are four stages in CKC, namely: (1) externalizing and sharing, (2) interpreting and analyzing, (3) negotiating and revising, and (4) combining and creating.

\section{RESEARCH METHOD}

The study was conducted on the learning patterns carried out by lecturers in the Exhibition Organizing course in the D4 MICE study program and the Sales Administration course at the D3 Business Administration - PNJ study program. The research method uses qualitative descriptive through the concept of Soft System Methodology [5,6] where there are 7 stages in SSM, namely: (1) unstructured problem situations, (2) expression of problem situations, (3) root definition of the relevant system in problem situations, (4) construction of model concepts, (5) comparisons between model concepts with real-world problem situations, (6) determination of needs and (7) possible changes and making changes to improve the situation. Data collection techniques are carried out through interviews with lecturers and leaders in departments and polytechnics, observation and documentation studies. The data obtained are then interpreted into the CATWOE concept approach (clients, actors, transformation, weltanschauung or world view, owners and environment).

\section{RESUlTS AND DATA ANALYSIS}

This study discusses the activities of lecturer teaching in D4 study program of MICE and D3 Business Administration PNJ.

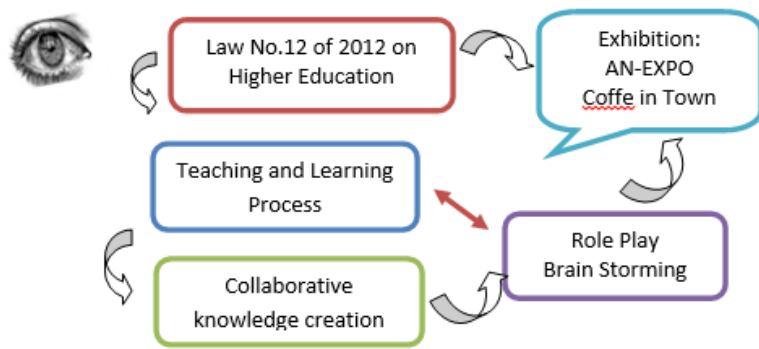

Fig. 1. Rich picture creative and innovative learning organizing through exhibitions.

In figure 2 describes how the collaborative knowledge creation using into exhibition event Coffee in Town 2018 and AN-EXPO 2017.

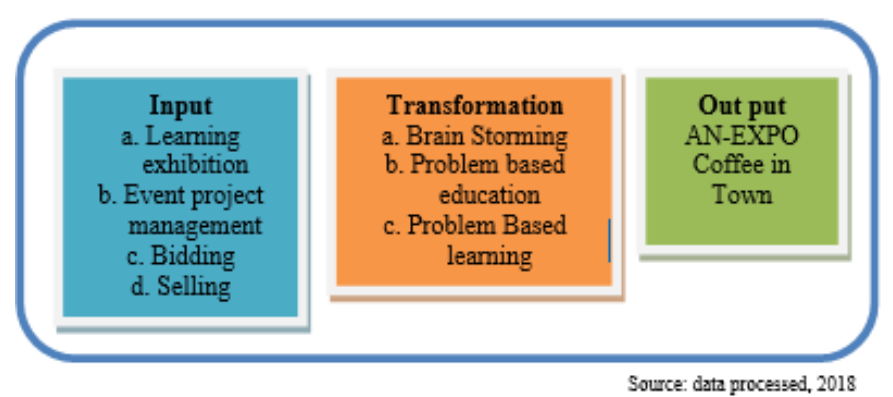

Fig. 2. Collaborative knowledge creation in learning exhibition.

To explain root definition (RD) how the concept of CKC using in learning process described in table 1.

TABLE I. RoOT DEFINITION FOR LEARNING PROCESS IN EVENT EXHIBITION

\begin{tabular}{|c|c|c|}
\hline $\begin{array}{c}\text { ROOT } \\
\text { DEFINITION }\end{array}$ & PROCESS & SYSTEM \\
\hline RD & $\begin{array}{l}\text { The process of } \\
\text { teaching and } \\
\text { learning process } \\
\text { using problem } \\
\text { based education } \\
\text { and problem based } \\
\text { learning with } \\
\text { collaborative } \\
\text { knowledge } \\
\text { creation }(\mathrm{CKC})\end{array}$ & $\begin{array}{l}\text { The system is owned and } \\
\text { operated by business } \\
\text { administration department in } \\
\text { the framework of policy } \\
\text { formulation (P) through the } \\
\text { improvement of interaction and } \\
\text { communication in externalizing } \\
\text { and sharing stage which can } \\
\text { overcome the asymmetry } \\
\text { information for challenge in } \\
\text { doing exhibition (Q) through } \\
\text { collaborative } \\
\text { creation (CKC) on policy } \\
\text { formulation process to improve } \\
\text { the teaching and learning. }\end{array}$ \\
\hline
\end{tabular}




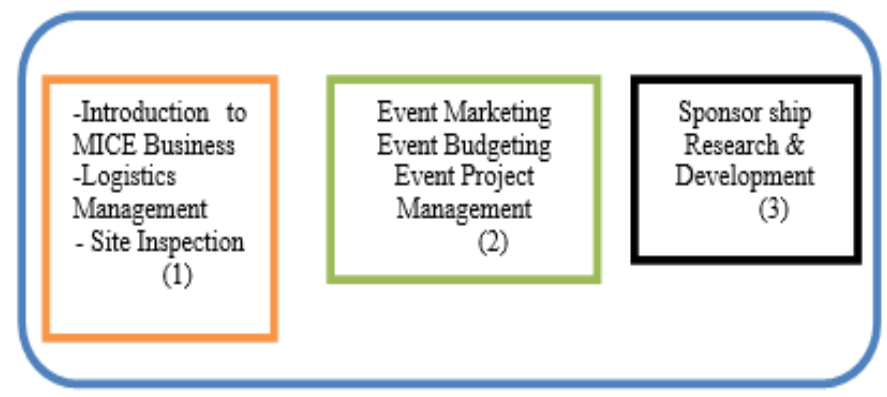

Source: data processed, 2018

Fig. 3. Series of exhibition subject.

The process carried out in the exhibition planning bidding is: the number of students in class A and class B is divided into several groups, each group consists of 3 students to make exhibition proposals. The proposal was competed each class through class bidding and 3 groups with the highest scores were taken as a winner. The results of the exhibition proposals which amounted to 6 proposals from class $\mathrm{A}$ and $\mathrm{B}$ then competed per class (Class bidding) so that one winner of the exhibition event proposal was chosen to be held as a force event. In the Coffee in Town 2018 event students good have knowledge and skill on how to relate to the media and sponsors. For further information about the event already done, can see it on the website: https://www.eventmicepnj.com/.

Here is a picture that explains the MICE event

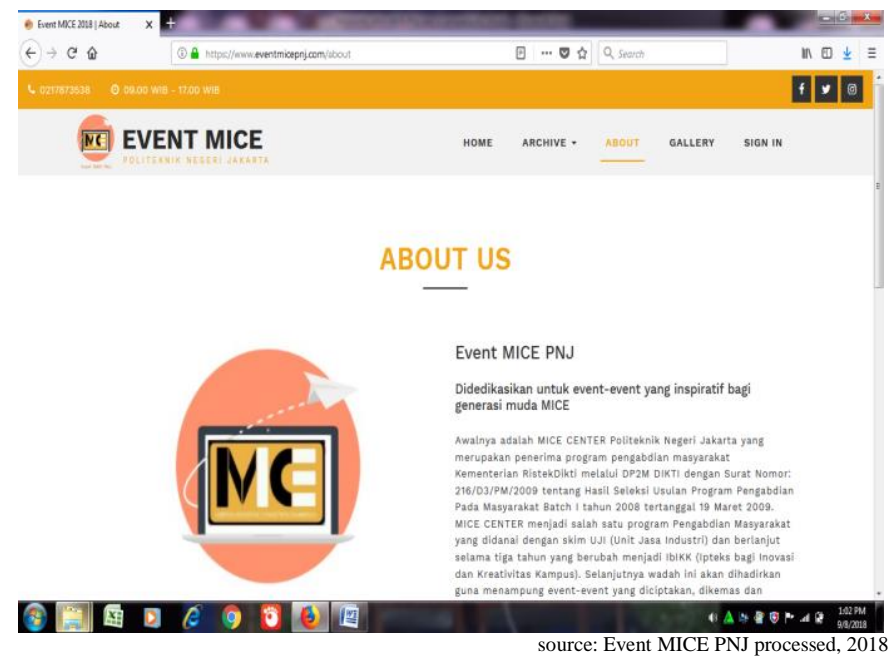

Fig. 4. Event MICE.

In learning method conducted by the lecturer, it gives students the freedom to ideas into the concept of the exhibition planning which in the end the idea and concept of the exhibition can really be carried out according to the proposal submitted in the bidding. In the implementation of AN-EXPO 2017, the number of students from 6 classes in the D3 Business Administration study program is divided into several groups, after bidding finally one of the proposal became a winner and organized for one week ANEX (AN-EXPO) activities. The winning group is responsible for all preparations, operations carried out by other groups that have a booth in AN-EXPO 2017 and the final evaluation of AN-EXPO activities is made in the form of an accountability report. Similar to the Coffee in Town event, students whose running An-EXPO 2017 should have good networking with media partners and sponsorships.

\section{TABLE II. CATWOE AND 3E}

\begin{tabular}{|l|l|}
\hline Customers & $\begin{array}{l}\text { Director, Assistant Director of academic fields, } \\
\text { Head of Department and Head of Study Program }\end{array}$ \\
\hline Actors & $\begin{array}{l}\text { Director, Assistant Director of academic fields, } \\
\text { Head of Department and Head of Study Program, } \\
\text { student }\end{array}$ \\
\hline Transformation & $\begin{array}{l}\text { Externalization and Sharing: in overcoming the } \\
\text { challenges of information asymmetry between } \\
\text { education providers }\end{array}$ \\
\hline Weltanschaung & $\begin{array}{l}\text { Submission of information is carried out to } \\
\text { produce strategies to strengthen the dynamic } \\
\text { capabilities of the organization }\end{array}$ \\
\hline Owner & $\begin{array}{l}\text { Director, Assistant Director of academic fields, } \\
\text { Head of Department and Head of Study Program }\end{array}$ \\
\hline Environment & $\begin{array}{l}\text { Limited time and costs } \\
\text { Externalization and sharing to overcome the } \\
\text { netwonges of information asymmetry in the } \\
\text { corporate and sponsorship }\end{array}$ \\
\hline E- Efficiency & \begin{tabular}{l} 
Limitations in budget and equipment \\
\hline E- Effective
\end{tabular} \\
\hline
\end{tabular}

Source: data processed, 2018

TABLE III. CREATIVE AND INNOVATIVE BASED LEARNING EDUCATION on EXHIBITIONS AT POLYTECHNiC Through Collaborative KNOWLEDGE CREATION

\begin{tabular}{|c|c|c|}
\hline NO & $\begin{array}{l}\text { LEVEL of } \\
\text { CKC }\end{array}$ & $\begin{array}{l}\text { CREATIVE AND INNOVATIVE BASED } \\
\text { EXHIBITION LEARNING }\end{array}$ \\
\hline 1 & $\begin{array}{l}\text { Externalizing } \\
\text { and Sharing }\end{array}$ & $\begin{array}{l}\text { a. Learning patterns refer to student center } \\
\text { learning (SCL) } \\
\text { b. Lecturers have knowledge, skills and } \\
\text { attitudes that are in accordance with the } \\
\text { material to be taught } \\
\text { c. Learning based on problem based education } \\
\text { and problem based learning }\end{array}$ \\
\hline 2 & $\begin{array}{l}\text { Interpreting } \\
\text { and } \\
\text { Analyzing }\end{array}$ & $\begin{array}{l}\text { a. Skill of the student: technical ability to } \\
\text { carry out events and must be passed by the } \\
\text { number of flight hours or experience in } \\
\text { carrying out the event. } \\
\text { b. Knowledge of the student: event knowledge } \\
\text { that needs to be possessed through } \\
\text { classroom learning (creating event } \\
\text { concepts, planning, implementing and } \\
\text { monitoring / evaluating an event). } \\
\text { c. Attitude of the student: face-to-face } \\
\text { behavior, however events are activities } \\
\text { that require interaction with people }\end{array}$ \\
\hline 3 & $\begin{array}{l}\text { Negotiating } \\
\text { and revising }\end{array}$ & $\begin{array}{l}\text { a. Lecturer have a good skill and knowledge } \\
\text { about running exhibition } \\
\text { b. Student have a good communication skill in } \\
\text { building network media partner } \\
\text { c. Student have a good relationship and } \\
\text { negotiation with industry and corporate } \\
\text { for sponsorship }\end{array}$ \\
\hline 4 & $\begin{array}{l}\text { Combining } \\
\text { and creating }\end{array}$ & $\begin{array}{l}\text { Lecturer, student, corporate, association of } \\
\text { business } \\
\text { knowledge creation in building exhibition. }\end{array}$ \\
\hline
\end{tabular}

Source: data processed, 2018 


\section{CONCLUSIONS}

The conclusions from this study:

- Collaborative knowledge creation has been implemented in the event;

- The role of leader in polytechnic should have a good vision to support learning processes such as exhibition doing with the student

- Lecturer has an experience and knowledge about running exhibition

- Competency of the student should have good knowledge and skills in communication skills for doing business events.

\section{SUGGESTIONS}

Running exhibition by the student from Polytechnic has a good chance for doing some business and making them excellent entrepreneurs if the leader of polytechnic has a good policy with supporting enough budget for the event.

\section{REFERENCES}

[1] G. Marlyng-Oey Gardiner, ERA DISRUPSION: Opportunities and Challenges of Indonesian Higher Education, Indonesian Academy of Sciences Prints II, June 2017, 2017.

[2] N. Forte, Freedom to Teach, Freedom to Learn, The Canadian Center for Policies and Alternatives, Our schools -Our selves, V.18 N.4 (\# 96), 2009. [Online] Retrieved from: http://www.policyalternatives.ca/sites/default/files/uploads/publications/ Our_Schools_Ourselve/OS_Summer09_5_nic k_forte.pdf

[3] W. Morris, Creativity in place in education, New Zealand, 2006. [Online] Retrieved from: Http://www.jpb.com/creative/Creativity_in_Education.pdf

[4] E. Du Chatenier, J.A. Verstegen, H.J. Biemans, M. Mulder and O. Omta, "The challenges of collaborative knowledge creation in open innovation teams," Human Resource Development Review, vol. 8, pp. 350-381, 2009.

[5] I. Mariam, Disertation: Collaborative Knowledge Creation At State Polytechnic of Jakarta to organization competitiveness (Action research based on Soft Systems Methodology), University of Indonesia, Depok, 2014.

[6] P. Checkland and J. Poulter, Learning for Action. New York, USA: John Wiley \& Son. 2006 